\title{
PUBLICATIONS FROM THE UNITED NATIONS
}

\section{Statistical Yearbook 1979-1980}

The new Statistical Yearbook covers through 1980 and provides a compendium of internationally comparable socio-economic statistics.

Data in the Statistical Yearbook makes it possible to study trends and changes in population and its composition, production, productivity, external trade, energy and transportation. Tables illustrate social statistics such as employment, housing. medical services and the consumption of fundamental commudities.

E/F.81.XVII.1

$\$ 60.00$

\section{UNBIS Thesaurus}

The principal information search and retrieval tool of the United Nations Bibliographic Information System (UNBIS): lists terms used to index and catalogue documents and other United Nations material.

E.81.J.17

$\$ 25.00$

\section{UNITED NATIONS}

Room A-3315

New York, N.Y. 10017

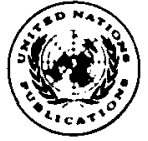

PUBLICATIONS

Palais des Nations 1211 Geneva 10, Switzerland

\section{CAMBRIDGE \\ War and Change in World Politics Robert Gilpin}

"In his search for a valid theory of international relations, Gilpin explores economic, sociological and political approaches and finds the essence of the international system, throughout history, in an ever-changing equilibrium threatened by the uneven growth of power among states. The book is rich in the use of history and the breadth of its analysis and it breaks new ground."-Foreign Affairs 


\section{FORO}

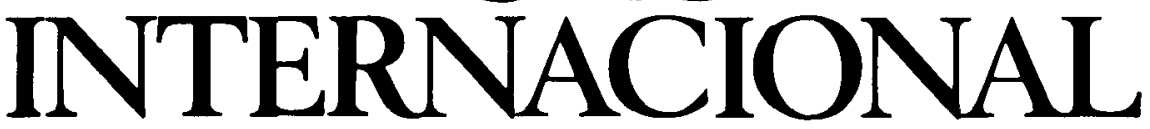

Revista trimestral publicada por El Colegio de México

\begin{tabular}{|c|c|}
\hline $\begin{array}{l}\text { Fundador: } \\
\text { Daniel Cosio Villegas }\end{array}$ & $\begin{array}{r}\text { Director: } \\
\text { Rafael Segovia }\end{array}$ \\
\hline Vol. XXI & io, 1981 \\
\hline $\begin{array}{l}\text { Artículos: } \\
\text { - Román Mayorga Quirós, } \\
\text { Una solución politica negociada } \\
\text { para El Salvador: Una propuesta } \\
\text { - Douglas Benneth y } \\
\text { Kenneth Sharpe, } \\
\text { El control sobre las multinacionales: } \\
\text { Las contradicciones de la } \\
\text { mexicanización } \\
\text { - Jorge Alberto Lozoya, } \\
\text { El Diálogo Norte-Sury } \\
\text { la diplomacia multilateral }\end{array}$ & $\begin{array}{l}\text { Conferencia: } \\
\text { - Bernardo Sepúlveda, } \\
\text { La regulación internacional de las } \\
\text { empresas tran'snacionales. } \\
\text { México ante el Diálogo Norte-Sur }\end{array}$ \\
\hline \multicolumn{2}{|c|}{$\begin{array}{l}\text { FORO INTERNACIONAL } \\
\text { Publicación Trimestral } \\
\text { Fecha__ } \\
\text { del banco_ } \\
\text { El Colegio de México importe de mi suscripción por__año(s) a la revisca Foro Internacional } \\
\text { Nombre_ }\end{array}$} \\
\hline & \\
\hline & \\
\hline
\end{tabular}

Suscripción anual en la República Mexicana: $\$ 320.00$ pesos

Suscripción anual para E.U., Canadá, Centro y Sudamérica (correo aéreo): \$19.50 U.S. dólares

Suscripción anual para el resto del mundo (correo aéreo) : \$27 U.S. dólares

Favor de enviar este cupón a: El Colegio de México, Departamento de Publicaciones, Camino al Ajusco 20, 10740 México, D.F. 
New

\section{Essays in Economics}

Theory and Policy by James Tobin

This new collection of Tobin's professional papers contains his most recent work, written mainly since 1974 . In five parts, it includes Tobin's writings on Monetary theory and policy; Macroeconomic fiscal policies and economic growth; International monetary economics (which deals with balance of payments adjustments, floating exchange rates, and a proposal for international monetary reform); Welfare and inequality; and portraits of other economists Tobin has known.

736 pp. $\$ 45.00$

\section{Strategies for Change}

The Future of French Society

by Michel Crozier

Foreword by Stanley Hoffmann

"Another pathbreaking contribution by one of Europe's foremost social scientists. The Future of French Society will be an important book for years to come. Incisive and cogently argued, it presents a realistic strategy for renewal that speaks to the heart of much of what's troubling all Western societies."-Professor Graham Allison, Dean, Kennedy School of Government, Harvard University

$256 \mathrm{pp} . \quad \$ 17.50$

\section{In paperback}

\section{The Atom Besieged} Antinuclear Movements in France and Germany by Dorothy Nelkin and Michael Pollak 256 pp. $\$ 7.95$
Competition and Control at Work

A New Industrial Sociology by Stephen Hill

$288 \mathrm{pp}$.

$\$ 25.00$ cloth, $\$ 9.95$ paper

The Brandt Report

North-South

A Program for Survival

$1980 \quad 304$ pp. $\$ 4.95$

28 Carleton Street

Cambridge, MA 02142 


\section{International Security}

a quarterly journal published by The MIT Press
Sponsored by

The Center for Science and International Affalrs, Kennedy School of

Government,

Harvard University
Michael Nacht

Albert Carnesale

Editors

Paul Doty

Chairman,

Editorial Board

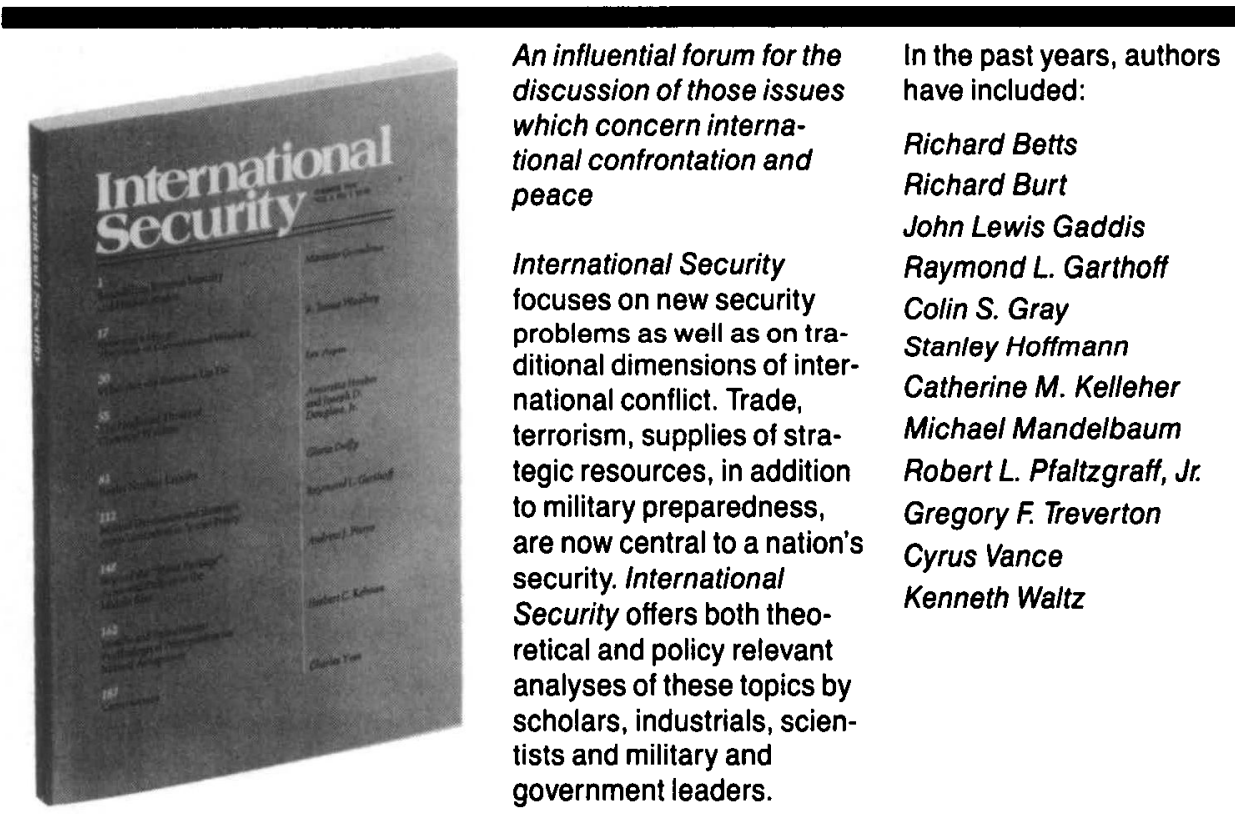

One Year (four issues)

$\square \$ 18.00$ individuals

$\$ 30.00$ Institutions

Check Enclosed

Charge to my Master

Card Account

4 digits above name

Charge to my VISA Account

Account \#

Expires
Outside U.S. and Canada, please add $\$ 4.00$ for surface and $\$ 18.00$ for airmail, annually.

Name

Address

State

Zip

International Security

The MIT Press

28 Carleton Street

Cambridge, MA 02142

Signed 


\section{International regimes}

International Organization volume 36, number 2, spring 1982

\section{Overviews}

Structural causes and regime consequences: regimes as intervening variables

Words can hurt you; or, who said what to whom about regimes

\section{Grotian perspectives}

International regimes:

lessons from inductive analysis

Regime dynamics: the rise and fall of international regimes

\section{Structural perspectives}

Coordination and collaboration: regimes in an anarchic world

The demand for international regimes

4. Cases

Security regimes

International regimes, transactions, and change: embedded liberalism in the postwar economic order

The transformation of trade: the sources and effects of regime change

Balance-of-payments financing: evolution of a regime

5. Conclusions, con and pro Cave! hic dragones: a critique of regime analysis

Regimes and the limits of realism: regimes as autonomous variables
Stephen D. Krasner

Ernst B. Haas

Donald J. Puchala and Raymond F. Hopkins

Oran $R$. Young

Arthur A. Stein

Robert O. Keohane

Robert Jervis John Gerard Ruggie Charles Lipson

Benjamin J. Cohen Susan Strange

Stephen D. Krasner

Sponsored by the World Peace Foundation, edited at Cornell University, and published by The MIT Press 